\title{
HEGEMONI KEKUASAAN DALAM NOVEL HUJAN KARYA TERE LIYE DAN IMPLIKASINYA DALAM PEMBELAJARAN BAHASA INDONESIA DI SMA
}

\author{
Primasari Wahyuni \\ Universitas PGRI Yogyakarrta \\ sariprima87@gmail.com
}

\begin{abstract}
Abstrak: Penelitian ini berujudul Hegemoni Kekuasaan Dalam Novel Hujan Karya Tere Liye dan Relevansinya Dalam Pembelajaran Bahasa Indonesia di SMA. Penelitian ini bertujuan untuk mndeskripsikan formasi ideologi, bentuk hegemoni kekuasaan, dan relevansi penelitian dengan pembelajaran Bahasa Indonesia di SMA. Jenis penelitian ini adalah deskriptif kualitatif. Sumber data penelitian ini adalah novel Hujan karya Tere Liye. Data penelitian berupa kata, frasa, atau kalimat yang memuat formasi ideologi dan bentuk hegemoni dalam novel Hujan karya Tere Liye, serta relevansinya dalam pembelajaran Bahasa Indonesia di SMA. Teknik pengumpulan data menggunakan baca dan catat. Teknik analisis data menggunakan content analysis. Validitas dan reliabilitas menggunakan validitas semantik dan intrarater. Hasil penelitian ini antara lain: 1) Pertama, Formasi ideologi dalam novel Hujan karya Tere Liye. Formasi ideologi yang ditemukan dalam novel Hujan karya Tere Liye yaitu otoritarisme, feodalisme, kapitalisme, liberalisme, sosialisme, serta vandalisme. Otoritarisme merupakan formasi ideologi yang paling banyak muncul dalam novel. 2) Kedua, bentuk hegemoni kekuasaan terjadi dalam masyarakat sipil dan masyarakat politik. 3) Ketiga, Relevansi penelitian dengan pembelajaran Bahasa Indonesia di SMA. Penelitian ini relevan dengan KD. 3.8 Mengidentifikasi nilai-nilai kehidupan yang terkandung dalam kumpulan cerpen yang dibaca. Melalui novel Hujan karya Tere Liye, siswa dapat mengapresiasi karya sastra sehingga menambah pengalaman, pengetahuan, dan wawasan yang dapat digunakan sebagai media untuk membentuk kepribadian diri.
\end{abstract}

Kata kunci: formasi ideologi, hegemoni, relevansi pembelajaran, novel

\section{THE HEGEMONY OF POWER IN NOVEL HUJAN BY TERE LIYE AND ITS RELEVANCE IN INDONESIA LEARNING AT HIGH SCHOOL}

Abstract: This research entitle "The Hegemony of Power in Novel Hujan by Tere Liye and Its Relevance in Indonesia learning at High School" has aims to describe the ideology formation, term of hegemony power, and the research relevance with Indonesia learning at high school. This research is a qualitative descriptive with data source is Npvel Hujan by Tere Liye. Research data are words, phrases pr sentences which has ideology formation and hegemony term and also the relevance with Indonesia learning at high school. Read and write were used to collect the data. Content analysis was used to analyze the data. Semantics and intrarater were used to test the validity and reliability. The reserach findings were : 1) the ideology formations were authoritarian, feudalism, capitalism, liberalism, socialism, and vandalism. Authoritarian was dominant in the novel, 2) the term of hegemony happened both in civil society and political society, 3) the relevance of this research with Indonesia learning at high school. This research was relevant with basic competence 3.8 (identify the life values in a short story. Novel hujan brught student to appreciate the literatures to enrich their experience, knowledge and insight to create the personality.

Keywords : Ideology formation, hegemony, learning relevance, novel.

\section{PENDAHULUAN}

Karya sastra merupakan bentuk imajinasi pengarang yang merefleksikan dan menggambarkan kehidupan dalam masyarakat. Karya sastra merupakan salah satu bentuk representasi budaya yang 
menggambarkan nilai-nilai yang dimiliki oleh masyarakat yang terdapat di sekitar pengarang atau bahkan merupakan kenyataan sosial budaya masyarakat yang melingkupi pengarangnya (Chatman, 1980:26). Gambaran kehidupan masyarakat seringkali disampaikan seorang pengarang melalui karya sastra meliputi kehidupan sosial, ekonomi, politik, juga budaya. Dalam hal ini, sastra bukanlah sesuatu yang otonom, melainkan sesuatu yang terikat erat dengan situasi dan kondisi lingkungan tempat karya itu dilahirkan (Jabrohim, 2015: 215). Sebagai sebuah bentuk refleksi kehidupan masyarakat, karya sastra menjadi wadah untuk mengungkapkan pikiran juga ekspresi pengarang mengenai gejala yang terjadi di masyarakat. Salah satu gejala sosial tersebut adalah adanya ketimpangan sosial yang terjadi di masyarakat.

Bentuk ketimpangan sosial di masyarakat dalam karya sastra disajikan dalam bentuk novel. Novel merupakan salah satu jenis karya sastra yang erat kaitannya dengan kehidupan masyarakat. Di dalam novel disajikan peristiwaperistiwa penting sebagai gambaran kehidupan atau sekedar luapan pemikiran dan ekspresi pengarang. Dari sudut pandang sosiologi, sastra atau novel merupakan sebuah cermin yang merefleksikan kondisi masyarakat serta tempat karya sastra itu tumbuh dan berkembang. Melalui karya sastra dapat dilihat bagaimana masyarakat pada zamannya. Novel dapat dianggap sebagai suatu usaha untuk menciptakan kembali dunia sosialnya, hubungan manusia dengan keluarga, lingkungan, pollitik, negara, budaya, dan sebagainya. Dengan demikian, sastra juga berurusan dengan struktur sosial, ekonomi, dan politik yang semua aspek tersebut juga menjadi urusan dalam sosiologi sastra (Damono, 1984:8). Melalui karya satra, seorang pengarang mengungkapkan problema kehidupan yang pengarang sendiri ikut berada di dalamnya. Pengarang sendiri adalah anggota masyarakat yang terikat status sosial tertentu dan tidak dapat mengelak dari adanya pengaruh yang diterimanya dari lingkungan yang sekaligus membentuknya.

Gambaran problema kehidupan masyarakat tergambar dalam novel Hujan karya Tere Liye. Novel Hujan menceritakan latar dunia pada tahun 2050an dengan tokoh utama dalam novel ini adalah Lail. Diceritakan dalam novel ini bahwa pada tahun 2050-an masyarakat dunia berada dalam masa segala kemajuan teknologi. Berbagai peralatan canggih dan modern termasuk mesin penghapus ingatan dijelaskan dalam novel tersebut. Permasalahan terjadi ketika bencana alam gempa bumi membumihanguskan sebagian besar masyarakat dunia. Bencana alam tersebut juga mengakibatkan adanya perubahan iklim ekstrem yang melanda masyarakat dunia. Di tengah isu genting untuk memecahkan masalah iklim para pemimpin dunia membuat kebijakan melakukan intervensi lapisan statosfer dengan mengirimkan peswat ulang-alik untuk mengatasi permasalahan tersebut. Intervensi lapisan statosfer merupakan tindakan yang dapat merusak lapisan udara. Akan tetapi, masyarakat dunia sepakat untuk mengambil keputusan tersebut. Keputusan tersebut hanya menyelesaikan permasalahan dalam jangka pendek. Tiga bulan berlalu, permasalahan yang sesungguhnya terjadi. Perubahan cuaca ekstrem terjadi. Hujan tidak lagi turun di bumi dan lambat laun manusia akan punah.

Kehidupan sosial masyarakat yang tergambar dalam novel Hujan karya Tere Liye merupakan salah satu wujud ketimpangan sosial dalam masyarakat. Salah satu bentuk ketimpangan sosial tersebut adalah adanya penjajahan kelompok sosial di masyarakat yang mendominasi kelompok lainnya. Fenomena penjajahan yang terjadi di masyarakat saat ini tidak lagi digambarkan melalui kekerasan secara fisik, tetapi melalui wilayah ideologi dan kebudayaan. Melalui cara inilah bentuk penjajahan bagi kelompok subordinat diterima sebagai sesuatu yang wajar dan tanpa paksaan 
(Kurniawati, 2016:32). Cara-cara penjajahan seperti itulah yang ditunjukkan dalam novel Hujan karya Tere Liye. Adanya kelompok sosial yang memimpin kelompok lainnya selanjutnya oleh Gramsci disebut hegemoni. Menurut Gramsci supermasi atau kelompok sosial menyatakan dirinya dalam dua cara, yaitu sebagai "dominasi" dan sebagai "kepemimpinan moral dan intelektual". Suatu kelompok sosial mendominasi kelompok-kelompok antagonistik yang cenderung ia "hancurkan" atau bahkan ia takhlukkan dengan kekuatan tentara atau kelompok tersebut memimpin kelompok yang sama dengan beraliansi dengannya (Patria \& Arief, 2009:117).

$$
\text { Hegemoni Gramsci menjadi }
$$

dimensi baru dalam Sosiologi Sastra. Hal ini menunjukkan bahwa kesusastraan tidak lagi dipandang semata-mata sebagai gejala kedua yang tergantung dan ditentukan oleh masyarakat kelas sebagai infrastrukturnya, melainkan dipahami sebagai kekuatan sosial, politik, dan kultural yang beriri sendiri dan memiliki sistem, meskipun tidak terlepas dari infrastrukturnya (Faruk sebagaimana dikutip oleh Pawestri, 2015:3). Secara singkat dapat dikatakan bahwa hegemoni adalah subordinasi kelompok terhadap kelompok lain yang tidak melalui cara-cara kekerasan. Kelompok subordinat akan menerima subordinasi dengan penerimaan yang wajar dan tanpa paksaan. Kelompok subordinat menerima ide-ide dan kepentingan politik kelompok yang berkuasa seperti layaknya kepunyaan mereka sendiri (Kurniawati, 2016:33).

Hegemoni yang dikembangkan oleh Gramsci tidak hanya sebatas dalam bidang politik. Hegemoni menyangkut persoalan ideologi dan kebudayaan. Hegemoni sebagai konsep yang dikembangkan oleh Gramsci menggambarkan bahwa dominasi suatu kelas (dominan) atas kelas lainnya (subordinat) terjadi karena aspek ideologiideologi politis. Hegemoni inilah yang menjadikan kekuasaan suatu kelas terhadap kelas lainnya bisa berlangsung.
Pemikiran Gramsci ini pada dasarnya telah menunjukkan perpisahan dari tradisi Marxis yang klasik. Hegemoni harus diperoleh melalui upaya yang bersifat politik, budaya, dan intelektual agar mampu menciptakan pandangan dunia secara bersama-sama bagi seluruh masyarakat. Dengan demikian, kelompok yang memegang kendali harus mampu menguniversalkan nilai-nilai dan pandangan dunia yang dimaksudkan tersebut demi kepentingannya dan juga kepentingan yang terhegemoni. Hegemoni harus diperoleh melalui perjuangan dengan langkah-langkah seperti kompromi dan konsolidasi yang terus-menerus agar situasi sosial, politik, dan yang lain dapat dikendalikan. Bila terjadi krisis sosial dan politik, kekuatan hegemoni harus tetap dipertahankan agar kendali dari hegemoni itu tidak dirampas oleh kelompok yang lain (Susanto sebagaimana dikutip Manan, 2015:27).

Gramsci mengemukakan tingkatan hegemoni, yaitu: hegemoni total (integral) yakni hegemoni yang itandai dengan afiliasi massa yang mendekati totalitas masyarakat menunjukkan tingkat kesatuan moral dan intelektual kokoh, hal ini tampat dalam hubungan organis antara pemerintah dan yang diperintah; hegemoni merosot (decadent hegemoni), masyarakat kapitalis modern dominasi ekonomis kaum borjuis menghadapi tantangan berat yang menunjukkan aanya potensi iintegrasi yag dapat menimbulkan konflik tersembunyi di bawah kenyataan sosial; hegemoni minimum (minimal hegemoni) bentuk hegemoni yang paling rendah dibanding dua bentuk sebelumnya, gehemoni ini bersandar pada kesatuan ideologis antara elit ekonomis, politik, dan intelektual yang terjadi secara bersamaan, akan tetapi enggan untuk mendapat campur tangan massa dalam hidup bernegara (Patria dan Arief, 2009: 118).

Teori Gramsci yang akan diterapkan dalam penelitian ini tergambar melalui gambaran kekuasaan pemimpin dunia yang melakukan subordinasi kepada masyarakat 
sehingga cara tersebut dapat diterima secara wajar. Melalui novel Hujan, pengarang menggambarkan realitas kehidupan sosial tentang hegemoni kekuasaan yaitu dominasi pemimpin dunia yang membuat kebijakan tanpa meminta persetujuan dari masyarakat yang tanpa disadari keadaan tersebut menimbulkan dampak-dampak bagi masyarakat yang terhegemoni.

Penelitian ini menggunakan metode kualitatif. Moleong (2006: 6) menjelaskan bahwa penelitian kualitatif adalah penelitian yang menghasilkan prosedur analisis yang tidak menggunakan proseur analisis statistik atau cara kuantifikasi lainnya. Fokus penelitian dalam penelitian ini adalah gambaran ideologi; hegemoni kekuasaan yang tercermin dalam novel Hujan karya Tere Liye, serta implikasi penelitian ini terhadap pembelajaran Bahasa Indonesia di sekolah. Data penelitian ini berupa kata-kata atau kalimat yang memuat gambaran hegemoni kekuasaan dan dampaknya bagi masyarakat di dalam novel Hujan karya Tere Liye, sedangkan sumber data dalam penelitian ini adalah novel Hujan karya Tere Liye yang diterbitkan oleh PT Gramedia Pustaka Utama pada tahun 2016.

Metode pengumpulan data dalam penelitian ini adalah baca catat untuk memperoleh data dengan cara membaca keseluruhan teks yang akan diteliti kemudian dicatat. Sebagai upaya untuk mengklasifikasi, mengelompokkan data maka penelitian ini menggunakan teknik analisis data (Sugiyono, 2012:244). Teknik analisis data dalam penelitian ini dilakukan dengan cara content analysis sebagai berikut. 1) membaca keseluruhan novel Hujan karya Tere Liye secara berulangulang secara teliti; 2) mengklasifikasikan data yang terkumpul; 3) melakukan analisis data yang telah diperoleh terkait dengan gambaran ideologi dan hegemoni kekuasaan; 4) mengaitkan hasil penelitian terhadap pembelajaran Bahasa Indonesia di sekolah; serta 5) menyimpulkan hasil analisis menjadi temuan penelitian. Penarikan kesimpulan dilakukan dengan merujuk kepada konsep tertentu sebagai parameter atau mencocokkan kesesuaian antara temuan data empiris di dalam fiksi dengan konsep tertentu. Keabsahan data diperoleh melalui validitas dan reliabilitas. Data disajikan dengan validitas semantik, yaitu proses menganalisis data yang berupa unit-unit kata, kalimat, wacana, dialog dan monolog sebagai data yang diperoleh sesuai konteks terhadap teks atau naskah, ssedangkan reliabilitas data yang digunakan adalah reliabilitas intrarater merupakan pembacaan berulang-ulang terhadap novel Hujan karya Tere Liye sampai dengan ditemukan kemantapan dan kepastian interpretasi.

\section{HASIL DAN PEMBAHASAN}

Sesuai dengan tujuan penelitian, hasil penelitian ini akan membahas tentang 1) formasi ideologi dalam novel Hujan karya Tere liye; 2) Bentuk hegemoni kekuasaan dalam novel Hujan karya Tere Liye; 3) Relevansi penelitian terhadap pembelajaran Bahasa Indonesia di SMA. Kekuasaan merupakan kemampuan seseorang atau sekelompok manusia untuk mempengaruhi tingkah laku orang lain. Kekuasaan dapat terjadi dalam berbagai macam hal, termasuk ideologi.

\section{A. Ideologi}

Beberapa ideologi dalam novel Hujan karya Tere Liye, kekuasaan digambarkan sebagai berikut.

\section{1) Otoritarisme}

Paham otoritarisme merupakan paham yang lebih mengandalkan pada kekuasaan (Mangunhardjana sebagaimana dikutip Pawestri, 2015: 33). Otoritarisme merupakan paham yang berpegang pada otoritas, kekuasaan, kewibawaan, termasuk cara hidup dan bertindak. Penganut paham ini berpegang pada kekuasaan sebagai acuan hidup, menggunakan wewenang sebagai dasar berpikir. Berikut ini adalah kutipan otoritarisme dalam novel Hujan karya Tere Liye: 


\begin{abstract}
"Pemirsa, Konferensi
Tingkat Tinggi mengenai perubahan iklim baru saja mengalami deadlock. Delegasi dari negara-negara subtropis memilih meninggalkan ruang konferensi. Mereka tetap pada rencana awal. Melakukan intervensi pada lapisan statosfer yang ditentang mati-matian oleh negara-negara tropis. Di studio bersama kami telah hadir narasumber untuk membahas informasi terkini”. (Liye, 2016: 121)

“.... Pemimpin negara mereka sejak awal sudah menginginkan intervensi lapisan statosfer, melenyapkan miliaran ton emisi gas sulfur dioksida. KTT itu hanya basa-basi, mereka tidak pernah bicara soal ilmu pengetahuan, pendekatan teknologi. Permasalahan itu sudah tentang politik. Konstelasi politik kawasan." (Liye, 2016:122).
\end{abstract}

Kutipan di atas menunjukkan otoritas kekuasaan yang dilakukan para pemimpin negara-negara di dunia. Adanya Konferensi Tingkat Tinggi yang seharusnya merupakan wadah diskusi untuk menyampaikan kebijakan melalui delegasi tiap-tiap negara, tetapi KTT tersebut hanya sebagai formalitas saja. Hal ini disebabkan karena para pemimpin dunia telah memutuskan untuk melakukan intervensi lapisan statosfer untuk mengatasi perubahan cuaca yang ekstrem di berbagai belahan negara di dunia. Meskipun mereka mengetahui bahwa adanya intervensi lapisan statosfer sangat berbahaya.

Otoritas kekuasaan yang dilakukan oleh para pemimpin negara dengan melakukan intervensi lapisan statosfer memberikan dampak positif dalam jangka pendek. Cuaca ekstrem yang sebelumnya terjadi, dalam kurun waktu tiga bulan dapat berubah menjadi terkendali. Akan tetapi, setelah enam bulan cuaca dingin ekstrem mulai terjadi. Di tengan pergolakan yang terjadi, para pemimpin negara melakukan otoritas kekuasaan dengan membuat keputusan sepihak dan tanpa bisa dibantah. Gambaran otoritas kekuasaan yang dilakukan oleh para pemimpin negara dalam novel Hujan karya Tere Liye tergambar dalam kutipan berikut ini.

"Tapi itu bukan keputusan saya. Itu keputusan pemimpin negeri. Dalam skala tertentu, keputusan itu lebih karena alasan politis. Menghentikan kerusuhan, mogok total. Yang jika dibiarkan, itu akan lebih dulu menghancurkan kita sebelum salju melakukannya. Sekali keputusan telah dibuat, maka tidak ada lagi yang bisa dilakukan untuk mencegahnya. Saya mengimbau agar penduduk tetap tertib, menunggu di rumah masing-masing, semoga pesawat ulang-alik itu membawa kabar baik. Kita tidak akan memperbaiki apa pun dengan keributan." (Liye, 2016:221)

Gambaran otoritas kekuasaan dalam novel Hujan karya Tere Liye juga tergambar melalui tokoh Soke Bahtera. 
Sebagai ilmuwan muda yang membuat berbagai peralatan canggih, Soke Bahtera memegang Lisensi Kelas A Sistem Keamanan yang jarang dimiliki kebanyakan orang. Soke Bahtera menggunakan kekuasaannya untuk mendapatkan keinginannya, termasuk dengan cara mengancam. Berikut kutipan di dalam novel.

"Buka pintunya, atau aku hancurkan!" Esok berteriak kalap.

"Tuan, aku tidak bisa melakukannya." Tabung mesin di depan ruangan kubus menolaknya.

"Aku Soke Bahtera! Pemegang Lisensi Kelas A Sistem Keamanan. Buka pintunya!"

Esok berhasil melewati meja pendaftaran dengan perintah itu-yang tidak bisa dilewati Maryam sepanjang malam. (Liye, 2016:312)

"Buka pintu itu, atau aku hancurkan!" Esok melepas salah satu besi tiang antrean, mengangkatnya tinggitinggi. Mengancam. Esok tidak peduli jika itu termasuk tindakan serius. (Liye, 2016:313)

\section{2) Sosialisme}

Sosialisme merupakan ideologi politik dalam rangka mencapai kemakmuran masyarakat dengan cara mengembangkan tindakan altruistik (tindakan yang berorientasi sosial) dan melembagakan kerjasama antarindividu (Nugroho, 2000:3). Gambaran tindakan sosialisme dalam novel Hujan karya Tere Liye ditunjukkan melalui tokoh Lail dan Maryam. Dua orang sahabat yang sama-sama tinggal di panti sosial setelah keluarganya meninggal akibat bencana alam gempa bumi. Adanya rasa senasib sepenanggungan, membuat rasa sosial tumbuh di dalam diri mereka. Hal tersebut tercermin ketika mereka mendapatkan penghargaan sekaligus uang sebagai relawan terbaik dalam sebuah organisasi sosial, mereka memberikannya kepada pengurus panti tempat mereka tinggal. Mereka bahkan tidak ingin menggunakan uang tersebut untuk keperluan pribadi. Dalam novel Hujan karya Tere Liye, sosialisme tersebut tergambar dalam kutipan berikut.

"Kami punya sesuatu untuk panti." Maryam mengeluarkan amplop dari saku.

"Ini apa?" Ibu Suri membuka amplop. Itu cek digital, berbentuk kartu pas biasa, tapi berisi saldo uang. Tinggal dibawa ke bank, ke ATM, atau mesin EDC. Saldo uangnya bisa ditransfer atau igunakan untuk membayar sesuatu.

"Hadiah yang kami terima di Ibu Kota," Lail yang menjawab, "untuk panti sosial."

Ibu Suri menatap Lail tidak percaya." Ini banyak sekali, Lail. Bahkan bisa kamu gunakan untuk membangun rumahmu.

"Aku tidak mau membangun rumah itu. Hanya mengembalikan kenangan lama." Lail menggeleng." Uang ini jauh lebih berguna bagi panti sosial. Kita tidak tahu apa yang akan terjadi satu-dua tahun ke depan, bisa saja kota kita 
mengalami musim dingin ekstrem. Uang ini bisa digunakan untuk membeli selimut, makanan, apa saja untuk keperluan penghuni panti."

"Aku juga tidak membutuhkan uangnya." Maryam menggeleng. (Liye, 2016:189)

Gambaran sosialisme juga ditunjukkan melalui tokoh sebagian pemimpin dunia yang tidak memiliki kepentingan politik, memutuskan untuk melakukan perubahan agar umat manusia dapat diselamatkan dari kepunahan. Mereka berusaha mencari solusi dari permasalahan yang ditimbulkan akibat keputusan sepihak para pemimpin dunia yang mementingkan kepentingan dalam jangka pendek akibat intervensi lapisan statosfer. Sebagian pemimpin negeri tersebut memutuskan untuk membuat teknologi canggih yang bisa menyelematkan umat manusia dari kepunahan. Gambaran sosialisme dalam novel Hujan karya Tere Liye tergambar dalam kutipan berikut.

$\begin{array}{lr}\text { "Umat manusia } & \text { harus } \\ \text { diselamatkan } & \text { dari } \\ \text { kepunahan. hanya tersedia } \\ \text { satu-satunya cara, yaitu } \\ \text { mengirim mereka } \\ \text { meninggalkan bumi. Setiap } \\ \text { kapal bisa menanmpung } \\ \text { sepuluh ribu penduduk, } \\ \text { membawanya ke orbit } \\ \text { seratus hingga dua ratus } \\ \text { kilometer dari bumi, jauh di } \\ \text { atas lapisan statosfer. } \\ \text { Mereka akan bertahan hiup } \\ \text { di sana. Kapal akan } \\ \text { memberikan tempat tinggal } \\ \text { yang didesain sedemikian } \\ \text { rupa seperti permukaan } \\ \text { bumi yang ideal. Hingga }\end{array}$

seratus tahun berlalu kapal berlayar, dan iklim bumi benar-benar pulih secara alami, mereka bisa mendarat lagi." (Liye, 2016:279)

Rasa perhatian sebagai salah satu ciri sosialisme ditunjukkan melalui tokoh Soke Bahtera. Salah satu ilmuwan muda yang berprestasi dalam membuat teknologi canggih dan modern. Seringkali wajahnya muncul di televisi dan majalah-majalah dengan sejumlah prestasi dan penghargaan. $\mathrm{Di}$ tengah kesibukannya, Soke Bahtera tetap memperhatikan Lail. Seorang gadis yang ia selamatkan ketika bencana gempa bumi terjadi beberapa tahun silam. Salah satu wujud perhatian Soke Bahtera terhadap Lail tergambar ketika masyarakat dunia mengalami kecemasan akibat adanya isu kepunahan manusia di muka bumi, dia berusaha menenangkan Lail. Dalam novel Hujan karya Tere Liye kutipan tersebut disajikan sebagai berikut.

"Apa yang harus aku lakukan, Esok?"

"sebelum kapal itu berangkat, kamu tunggu kabar dariku. Apapun yang kamu dengar, apa pun informasi yang kamu terima, jangan lakukan apa pun. Tunggu aku menghubungimu. Kamu bisa melakukan aktivitas seperti biasa dengan normal, karena hanya itu yang bisa kita lakukan. Aku harus kembali ke lokasi proyek, masih ada satu hal yang harus kuselesaikan terkait kapal-kapal itu. Tugas terakhirku." (Liye, 2016:281) 


\section{3) Feodalisme}

Feodalisme merupakan paham yang muncul dalam bentuk perbedaan bentuk bahasa yang menunjukkan tingkat kedudukan (Shadily sebagaimana dikutip oleh Harjito, 2014:30). Gambaran feodalisme dalam novel Hujan karya Tere Liye ditunjukkan melalui tokoh Wali Kota. Sebagai salah satu bagian dari aparat pemerintahan, Wali Kota menggunakan jabatan tersebut untuk mendapatkan keinginannya. Di tengah adanya rencana peluncuran kapal penyelamat manusia yang tidak bisa membawa seluruh jumlah masyarakat dunia, Wali Kota meminta kepada Lail agar tiket bisa diberikan kepada anaknya.

"Lail, izinkan orang tua ini memohon kepadamu. "Wali Kota memegang tangan Lail, wajah pahlawan kota itu terlihat lebih tua daripada usianya, matanya berkacakaca.

"Aku tahu, Esok akan menggunakan satu tiket lagi untukmu. Dia sangat menyayangimu, Lail. Tapi izinkan orang tua ini memohon, bisakah kamu meminta Esok agar memberikan tiket itu kepada Claudia, anak semata wayangku? Aku, istriku, kami tidak akan pernah sanggup menyaksikan Clauia harus tinggal di permukaan bumi, menunggu musim panas membunuh semua orang. Hanya Claudia satu-satunya putri yang kami miliki. Satu-satunya harga paling berharga." (Liye, 2016:290).

\section{4) Kapitalisme}

Kapitalisme merupakan paham yang menganut kebebasan individu. Dua hal yang saling berpasangan dalam kapitalisme adalah kekayaan dan kebebasan individu. Elemen kesadaran kapitalisme adalah kekayaan merupakan segala-galanya, kekayaan merupakan daya penggerak di semua kehidupan manusia. Elemen kebebasan adalah kepemilikan kekayaan oleh individu (Harjito, 2014:44). Pemilikan kekayaan individu atau swasta yang merupakan elemen kebebasan dalam novel Hujan karya Tere Liye tergambar melalui tokoh sebagian pemimpin negeri yang membiayai pembuatan kapal untuk menyelamatkan umat manusia. Kutipan tersebut terlihat berikut.

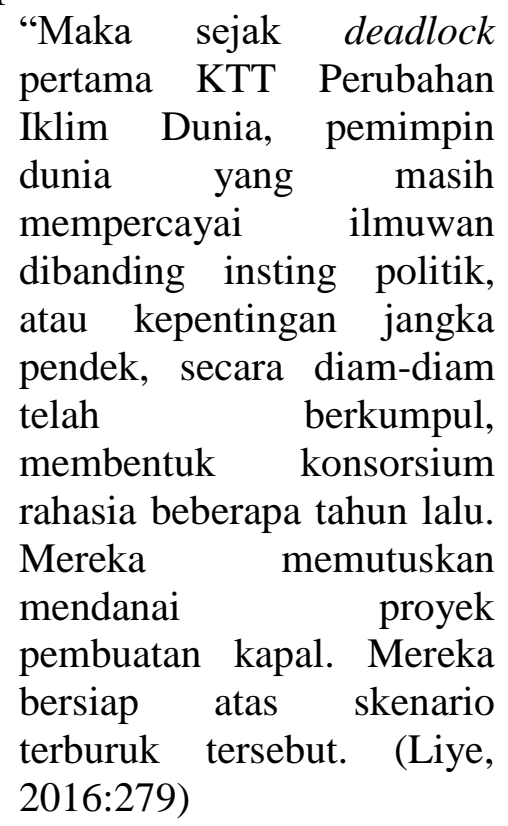

\section{5) Liberalisme}

Kapitalisme tidak dapat dipisahkan dengan tradisi liberalisme dan demokrasi. Liberalisme merupakan paham yang menekankan kebebasan individu. Beberapa ciri liberalisme, yakni: mendukung perubahan; percaya kepada nalar manusia; menerima campur 
tangan pemerintah dalam meningkatkan kondisi manusia; mendukung kemerekaan individu, tetapi tidak merasa pasti mengenai kemerdekaan ekonomi; serta ambivalen terhadap hakikat manusia (Harjito, 2014:48). Gambaran liberalisme dalam novel Hujan karya Tere Liye ditunjukkan melalui tokoh empat pemimpin negeri yang mendukung adanya perubahan sebagaimana kutipan berikut.

Menghadapi ancaman nyata kepunahan manusia, empat negara bersepakat memulai proyek pembuatan kapal. Dipimpin oleh ilmuwanilmuwan dari universitas terbaik. Umat manusia tidak boleh punah. Kita harus mencari cara agar hingga ribuan tahun lagi generasi berikutnya tetap hidup. Tidak di permukaan bumi, melainkan mengirim mereka ke angkasa, hingga bumi kembali pulih. (Liye, 2016:288)

Kutipan di atas menunjukkan bahwa empat pemimpin negeri yang tidak memiliki kepentingan politik merasa tergugah untuk melakukan perubahan atas permasalahan cuaca ekstrem yang mengancam kepunahan manusia. Keinginan untuk melakukan perubahan tersebut dilakukan dengan menggunakan modal atau biaya pribadi yang merupakan salah satu ciri dari liberalisme.

\section{6) Vandalisme}

Vandalisme merupakan perbuatan merusak dan menghancurkan hasil karya seni dan barang berharga lainnya secara kasar (KBBI Online). Vandalisme dalam novel Hujan karya Tere Liye muncul melalui tokoh Soke Bahtera. Sebagai seorang ilmuwan muda yang berprestasi, Soke Bahtera menciptakan berbagai teknologi canggih, salah satunya adalah mobil digital. Dalam keadaan terdesak, Soke melakukan perusakan pada mobil tersebut dengan kasar. Hal tersebut tergambar dalam kutipan berikut.

"Ya Tuhan!" Esok panik, menyadari situasi, lalu berlari menuruni tangga stasiun kereta.

Ada mobil mewah terparkir di lobi kedatangan.

Esok memukul jendela kacanya, membuka pintu secara paksa.

"Tuan, aku memperingatkanmu,

mengendarai mobil milik orang lain adalah pelanggaran serius. Dikategorikan sebagai pencurian," mobil itu "berbicara".

"Otorisasi kode D210579, aku Soke Bahtera, delapan puluh persen teknologi terbang yang ada di mobilmu sekarang adalah hak patenku, aku yang menemukannya. Aku berhak mengambil alih mobil apa pun. Segera terbang ke Pusat Terapi Saraf."

Kutipan di atas menunjukkan bahwa tokoh Soke Bahtera melakukan perusakan terhadap hasil karya sendiri saat berada di depan stasiun kereta api dan mendapat informasi bahwa Lail akan menghapus semua memori ingatannya.

\section{B. Hegemoni Dalam Novel Hujan Karya Tere Liye}

Gramsci membagi wilayah hegemoni menjadi dua, yaitu 
masyarakat sipil dan masyarakat politik. Masyarakat sipil merupakan wilayah yang menjadi kesetujuan dan kehendak bebas yang dilakukan oleh aparat-aparat hegemoni terhadap wilayah yang dikuasainya demi memenangkan kesetujuan dari masyarakat yang dikuasai ; seangkan masyarakat politik merupakan wilayah dunia kekerasan, pemaksaan, dan intervensi yang dilakukan aparataparat penguasa (Faruk, 2003:77).

\section{1) Masyarakat Sipil}

Bentuk-bentuk hegemoni kekuasaan dalam masyarakat sipil dalam novel Hujan karya Tere Liye ditemukan sebagai berikut.

\section{a) Pemimpin yang Berkuasa}

Dalam novel Hujan
karya Tere Liye
pemimpin yang berkuasa
ditunjukkan melalui beberapa
tokoh, diantaranya adalah para
pemimpin negara subtropis
dunia yang memutuskan
melakukan intervensi lapisan
statosfer secara sepihak.
Keputusan tersebut tidak dapat
dicegah, meskipun
mendapatkan penolakan dari
negara-negararara tropis.

Tindakan tersebut merupakan tindakan yang konyol karena intervensi lapisan statosfer justru merusak lapisan statosfer. Konferensi Tingkat Tinggi telah dilakukan melalui delegasi antarnegara. Akan tetapi pertemuan tersebut menjadi sia-sia karena para pemimpin negara subtropis tetap bersikukuh dengan keinginannya. Gambaran pemimpin yang berkuasa dalam novel Hujan karya Tere Liye tersaji dalam kutipan berikut.

Apa yang terjadi jika sebuah negara kehilangan seluruh penduduknya? Tidak ada lagi otoritas negara-negara di kawasan subtropis. Pemimpin negara mereka sejak awal sudah menginginkan intervensi lapisan statosfer, melenyapkan miliaran ton emisi gas sulfur dioksida. KTT itu hanya basa-basi, mereka tidak pernah bicara soal ilmu pengetahuan, pendekatan teknologi. Permasalahan ini sudah tentang politik. Konstelasi politik kawasan" . (Liye, 2016:122)

"Tapi itu berbahaya, bukan? Bagaimana jika intervensi justru merusak lapisan statosfer?"

"Itu tidak berbahaya." Narasumber menggeleng, wajahnya datar. "Tapi itu amat sangat berbahaya. Konyol. Anda ingat percakapan kita tiga tahun lalu? Beberapa detik sebelum gunung meletus dan menghancurkan dua benua?"

Pembawa acara mengangguk. (Liye, 2016:123)

Keputusan yang diambil oleh para pemimpin negeri adalah hal yang tidak bisa dicegah. Hal tersebut merupakan salah satu ciri pemimpin yang berkuasa. Dalam novel Hujan karya Tere Liye tersaji sebagai berikut.

"Tapi itu bukan keputusan saya. Itu keputusan pemimpin negeri. Dalam skala tertentu, keputusan itu lebih karena alasan politis. Menghentikan kerusuhan, mogok total. Yang jika dibiarkan, itu akan lebih 
dulu menghancurkan kita sebeum salju melakukannya. Sekali keputusan telah dibuat, maka tidak ada lagi yang bisa ilakukan untuk mencegahnya. (Liye, 2016:221)

Sudah tertutupnya akal sehat para pemimpin negara subtropis untuk menrima masukan pendapat dari negaranegara tropis membuat Konferensi Tingkat Tinggi mengalami jalan buntu. Para pemimpin negara subtropis tersebut bahkan memilih meninggalkan ruang konferensi. Berikut kutipan dalam novel Hujan karya Tere Liye.

"Pemirsa, Konferensi Tingkat Tinggi mengenai perubahan iklim baru saja mengalami deadlock. Delegasi dari negara-negara subtropis memilih meninggalkan ruang konferensi. Mereka tetap pada rencana awal. Melakukan intervensi pada lapisan statosfer yang ditentang mati-matian oleh negara-negara tropis. Di studio bersama kami telah hair narasumber untuk membahas informasi terkini dunia." (Liye, 2016:121)

Gambaran pemimpin
yang berkuasa ditunjukkan
melalui tokoh Wali Kota.
Dalam novel Hujan karya Tere
Liye, tokoh Wali Kota
digambarkan sebagai sosok
yang ramah serta bertanggung
jawab terhadap perkerjaan dan
masyarakat di wilayahnya.
Adanya intervensi lapisan
statosfer menyebabkan

perubahan iklim ekstrem terjadi di berbagai belahan dunia, termasuk negara-negara tropis. Suhu panas meningkat drastis, awan hilang dari langit. Para ilmuwan memprediksi bahwa dalam waktu enam bulan yang akan datang hujan tidak akan lagi turun. Dalam kondisi yang kritis tersebut, para ilmuwan sepakat untuk menyelamatkan umat manusia dengan membuat teknologi canggih berupa kapal ke luar angkasa. Akan tetapi, kapal tersebut hanya bisa mengangkut sepuluh ribu dari jumlah manusia di dunia. Tidak semua penduduk mendapatkan tiket untuk menaiki kapal tersebut. Pada saat itulah, Wali Kota menggunakan kekuasaannya sebagai pemimpin untuk mendapatkan tiket tersebut untuk anak semata wayangnya. Berikut kutipan dalam novel Hujan karya Tere Liye.

"Aku menghabiskan puluhan tahun mengabdi untuk kota kita. Tidak masalah namaku tidak termasuk dalam daftar penumpang. Jika aku memiliki tiket itu, aku bahkan bersedia memberikannya ke orang lain. Termasuk istriku. Dia bahkan bersumpah tidak akan menerima tiket itu. Dia akan memperioritaskan orang lain. Sayangnya, namanya juga tidak ada." Wali Kota terdiam lagi, suaranya serak. (Liye, 2016:289)

Aku tahu karena aku punya akses melihat daftar nama." 
"Lail, izikan orang tua ini memohon kepadamu." Wali Kota memegang tangan Lail, wajah pahlawan kota itu terlihat lebih tua daripada usianya, matanya berkacakaca.

"Aku tahu, Esok akan menggunakan satu tiket lagi untukmu. Dia sangat menyayangimu, Lail. Tapi izinkan orang tua ini memohon, bisakah kamu meminta Esok agar memberikan tiket itu kepada Claudia, anak semata wayangku? Aku, istriku, kami tidak akan pernah sanggup menyaksikan Claudia harus tinggal di permukaan bumi, menunggu musim panas membunuh semua orang. Hanya Claudia satu-satunya putri yang kami miliki. Satu-satunya harta paling berharga." (Liye, 2016:290)

\section{b) Pertentangan}

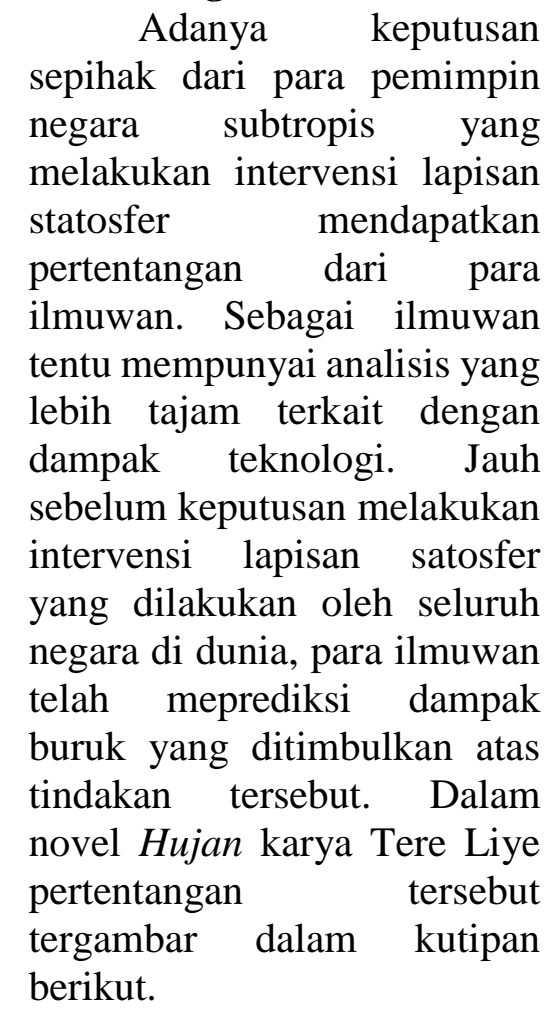

Sepanjang pagi televisi menyiarkan berita, siaran langsung dari pusat antariksa Ibu Kota, ketika dua belas pesawat ulang-alik berbaris di landasan pacu.

"Dengan pengumuman tadi malam dari pemimpin negeri, yang diikuti oleh belasan negara tropis lainnya, maka resmi sudah seluruh negara melakukan intervensi. Apa komentar Anda?"

Pembawa acara yang amat dikenal Lail terlihat di layar kaca.

"No comment," narasumber yang juga amat dikenal Lail menjawab singkat.

"Tapi Anda pernah bilang tindakan ini amat sangat bodoh. Maka seluruh negara sepertinya sudah amat sangat bodoh jika mengacu versi Anda?"

"No comment."

"Atau sebaliknya, ketika sebenarnya negara-negara subtropis ternyata berhasil memulihkan iklim mereka setahun terakhir lewat intervensi itu, bisa jadi pendapat Anda dulu yang sangat keliru?"

"No comment," narasumber itu tetap menjawab tidak peduli.

Lail menatap layar televisi lamat-lamat. Sebenarnya itu percakapan yang amat ganjil. Narasumber terlihat sangat jengkel, membuatnya tidak menjawab satu pun pertanyaan dari pembawa acara, kecuali no comment.

Para ilmuwan sangat menyayangkan pengiriman pesawat ulang-alik untuk 
mengintervensi lapisan statosfer. Bukan hanya hujan yang tidak akan turun, tetapi suhu udara diproyeksikan akan meningkat signifikan beberapa tahun ke depan, musim panas ekstrem mulai terjadi di negara-negara subtropis. Kekecewaan tersebut tergambar dalam kutipan berikut.

Breaking news!

"Partikel anti gas sulfur dioksida telah mengkhianati kita," narasumber di televisi menjawab datar.

"Tapi bagaimana jika kita melakukan intervensi atas intervensi anti gas sulfur dioksida tersebut? Agar awan kembali terbentuk?"'

Pembawa acara melontarkan ide.

"Ide konyol. Itu hanya akan mempercepat proses kepunahan umat manusia." Narasumber menatap meja, meraih gelas di depannya." Akan saya berikan contoh sederhana. Air di gelas ini jernih, hingga datanglah seseorang yang ngotot ingin warnanya menjadi merah. Mudah melakukannya, tuangkan pewarna merah, jadi merah airnya. Tapi ketika datang lagi seseorang yang ngotot ingin warnanya menjadi kuning, bagaimana caranya? Silakan tuangkan pewarna kuning sebanyak mungkin, hasilnya tidak akan pernah kuning."

"Tapi bagaimana kita mengatasi masalah ini sekarang/"

"Tidak ada jalan keluar lagi. Kita tidak bisa menyeot miliaran gas yang telah tercampur di langit, lantas

membuangnya ke planet

Mars. (Liye, 2016:269)

Pertentangan terhadap para pemimpin yang berkuasa juga dilakukan oleh masyarakat sipil biasa. Elijah adalah seorang perawat senior yang bekerja di rumah sakit yang sejak musim dingin melanda, seringkali melihat dampak buruk adanya intervensi lapisan statosfer yang dilakukan para pemimpin negara-negara di dunia. Hal tersebut yang membuat hatinya miris dan menolak keputusan pemimpin melakukan intervensi. Dalam novel Hujan karya Tere Liye tergambar dalam kutipan berikut.

"Aku juga tidak setuju atas intervensi itu, Lail." Elijah menghela napas panjang." Tapi saat itu aku perawat yang bekerja di rumah sakit Ibu Kota. Mungkin tiak sebanding dengan pengalamanmu di Sektor 1 . Tapi setiap hari, di rumah sakit, sejak musim dingin melanda kota, selalu ada anak-anak meninggal karena kelaparan, orang tua sakit tidak tertolong. Kami pasti tahu, proses penyembuhan membutuhkan asupan gizi. (Liye, 2016:223)

Kutipan di $\begin{array}{r}\text { atas } \\ \text { bahwa }\end{array}$
menunjukkan selamanya
kekuasaan tidak
berjalan lancar karena dalam
masyarakat pasti ada yang
tidak setuju atau melakukan
perlawanan, baik secara
terbuka atau terselubung
(Scott dikutip Pawestri, 2015:
48).


2) Masyarakat Politik

Bentuk-bentuk hegemoni kekuasaan dalam novel Hujan karya Tere Liye dibahas sebagai berikut.

\section{a) Tindakan Mengancam}

Tindakan mengancam merupakan salah satu ciri bagian dari masyarakat politik. Masyarakat politik merupakan wilayah dunia kekerasan, pemaksaan, dan intervensi yang dilakukan aparat-aparat penguasa (Faruk, 2003:77). Tindakan kekerasan dan pemaksaan, serta intervensi dilakukan oleh Soke Bahtera. Seorang ilmuwan muda dengan banyak prestasi dalam pembuatan teknologi canggih. Sebagai ilmuwan yang terkenal, ia merupakan salah satu pemegang lisensi kelas A sistem keamanan. Rasa kalap yang meluap dalam dirinya membuat ia melakukan segala cara agar dapat mencegah tindakan Lail menghapus semua memori ingatan di Pusat Terapi Saraf. Berikut kutipan dalam novel Hujan karya Tere Liye.

"Buka pintu itu, atau aku hancurkan!" Esok melepas salah satu besi tiang antrean, mengangkatnya tinggitinggi. Mengancam. Esok tidak peduli jika itu termasuk tindakan serius. Terdengar suara mendesing pelan. Pintu itu akhirnya terbuka. (Liye, 2016:313)

\section{b) Pasrah pada Penguasa}

\begin{tabular}{lrr}
\multicolumn{2}{c}{ Keputusan para } \\
pemimpin negeri untuk \\
melakukan intervensi lapisan \\
statosfer & menimbulkan \\
dampak buruk. Seperti apa
\end{tabular}

yang telah diprediksi oleh para ilmuwan, bahwa intervensi tersebut menyebabkan cuaca ekstrem melanda seluruh kota. Hal ini menyebabkan musim paceklik pangan. Dampak buruk dirasakan oleh seluruh penduduk negeri. Salah satunya adalah Ibu Esok. Sebagai seorang penjual kue, musim panas yang ekstrem menyebabkan bahan kue sulit ditemui. Dengan rasa pasrah, Ibu Esok akan menutup toko kuenya. Berikut gambaran dalam novel Hujan karya Tere Liye.

"Apa kabar, Bu?" Lail bertanya.

"Ibu sehat. Tapi toko ini tidak, Lail." Ibu Esok menggerakkan kursi rodanya, berdesing tanpa suara. Kursi bergerak mulus di lorong rak-rak.

Dibandingkan dengan sebulan lalu, isi toko berkurang separuhnya. Kuekue kering tidak banyak lagi dipajang di rak. Toko terlihat suram.

"Terigu, gandum, gula, semakin sulit diperoleh. Apalagi telur. Mendapatkan beberapa butir saja sangat sulit." Ibu Esok menghela napas. Wajahnya tampak sedih.

Lail mengangguk. Krisis bahan pangan semakin serius melanda kota mereka. (Liye, 2016:2003)

"Kalian tidak perlu lagi datang kemari bulan depan, Lail, Maryam." Ibu Esok mengantar hingga ke pintu, suara lonceng terdengar lembut. 
"Eh, kenapa, Bu?" Maryam tidak mengerti.

"Besok toko ini ditutup. Ibu tidak punya lagi bahanbahan untuk membuat kue." Wajah Ibu Esok terlihat lesu (Liye, 2016:204)

c) Menyusun

Mengalahkan Penguasa

Sejak ada keputusan intervensi lapisan statosfer yang dilakukan oleh para pemimpin dunia, hal ini memunculkan pro dan kontra di masyarakat. Bagi kelompok yang menentang intervensi ini kemudian secara diam-diam bergabung untuk menyusun strategi menghadapi ancaman nyata kepunahan manusia akibat intervensi lapisan statosfer. Berikut kutipan dalam novel Hujan karya Tere Liye.

"Delapan tahun lalu, setelah deadlock KTT Perubahan Iklim Dunia, beberapa pemimpin dunia melakukan pertemuan tertutup. Ada empat kepala negara, delapan gubernur, dan walikota kota-kota besar di dunia. Aku termasuk salah satunya.

Dalam pertemuan itu juga hadir sebelas ilmuwan terkemuka, salah satunya adalah profesor yang sering muncul di televisi, dengan pernyataan yang tidak disukai penonton. (Liye, 2016:288)

Menghadapi ancaman nyata kepunahan manusia, empat negara bersepakat memulai proyek pembuatan kapal. Dipimpin oleh ilmuwanilmuwan dari universitas terbaik. Umat manusia tidak boleh punah. Kita harus mencari cara agar hingga ribuan tahun lagi generasi berikutnya tetap hidup. Tidak di permukaan bumi, melainkan mengirim mereka ke angkasa, hingga bumi kembali pulih. (Liye, 2016:288)

d) Mengatur

Strategi Menyingkirkan Penentang

Hegemoni tidak pernah dapat diperoleh begitu saja, tetapi harus diperjuangkan secara terus-menerus (Simon, 2004:45). Adanya pro dan kontra yang muncul di masyarakat negara-negara tropis akibat peluncuran pesawat ulang-alik sebagai intervensi lapisan statosfer tidak menyurutkan niat dari negara-negara subtropis untuk terus mempertahankan keputusan. Negara-negara subtropis tersebut menunjukkan rasa egois dan tidak peduli dengan negaranegara tropis yang pernah membantunya. Mereka membiarkan negara-negara tropis kekurangan bahan pangan dalam situasi cuaca ekstrem. Dalam novel Hujan karya Tere Liye tergambar dalam kutipan berikut.

"Kondisi kita akan jauh lebih baik jika negaranegara subtropis yang situasinya sudah pulih bersedia mengirimkan puluhan kapal berisi bahan pangan," salah satu relawan senior berkomentar dalam briefing di markas.

"Itu benar. Selama tiga tahun saat mereka dilanda musim dingin ekstrem, kota ini mengirimkan ribuan kapal bantuan. 
Sekarang? Mereka memilih diam, hanya menonton," yang lain menimpali.

"Mereka tidak akan peduli," relawan senior lainnya ikut berdiskusi. "Setahun lalu saat mereka meminta persetujuan intervensi lapisan statosfer, negaranegara tropis menolaknya. Dan situasi semakin rumit karena mereka juga tidak terima disalahkan begitu saja atas bergesernya iklim ekstrem ke ekuator. Argumen mereka selalu sama dalam setiap pertemuan. (Liye, 2016:216)

\section{Relevansi Dalam Pembelajaran Bahasa Indonesia}

Karya sastra merupakan karya imajinasi pengarang yang mencerminkan kehidupan sosial di masyarakat. Dalam pendidikan, sastra berperan untuk mengembangkan aspek kognitif, afektif, psikomotorik, serta kepribadian siswa. Melalui karya sastra, dapat membentuk pendidikan karakter siswa seperti nilai sosial, agama, moral, dan budaya. Karena merupakan karya imajinatif, karya sastra dapat membentuk pola pikir dan respon pembaca terhadap apa yang dibacanya. Salah satu pembentukan karakter siswa dapat dilakukan dengan mengapresiasi karya sastra.

Novel Hujan karya Tere Liye merupakan salah satu novel yang layak untuk diapresiasi. Novel Hujan karya Tere Liye merupakan suatu media siswa untuk mempelajari banyak hal tentang kehidupan sosial, moral, serta budaya. Hal ini relevan dengan pembelajaran Bahasa Indonesia di SMA dalam KD. 3.8. Mengidentifikasi nilai-nilai kehidupan yang terkandung dalam kumpulan cerita pendek yang dibaca.
Melalui novel Hujan karya Tere Liye siswa dapat digunakan siswa untuk menambah pengalaman, pengetahuan, dan wawasan yang dapat digunakan sebagai media untuk membentuk kepribadian diri. Beberapa karakter pembentuk kepribadian dalam novel Hujan karya Tere Liye antara lain:

\section{Sifat Mandiri dan Pantang Menyerah}

Sifat mandiri dan pantang menyerah digambarkan melalui tokoh Lail. Sebagai tokoh utama perempuan dalam novel ini, Lail memiliki karakter yang patut dipuji. Sejak berusia dua belas tahun, Lail menjadi anak yatim piatu. Kedua orang tuanya meninggal akibat bencana gempa bumi yang terjadi akibat letusan gunung berapi yang dahsyat. Sejak saat itu, Lail melanjutkan kehidupan di panti sosial. Kehidupan yang penuh kedisiplinan di panti sosial membuat Lail tumbuh menjadi gadis yang mandiri dan pantang menyerah. Berbagai kegiatan diikuti, termasuk menjadi relawan di sebuah organisasi sosial. Keikutsertaan di organisasi sosial tersebut mengantarkan Lail mendapatkan penghargaan di tingkat internasional. Semangat Lail terus berkobar, dia bercitacita ingin menjadi seorang perawat. Di sela-sela kegiatan menjadi relawan, Lail tetap giat belajar demi bisa masuk ke akademi perawat sesuai yang dicita-citakan. Berkat kerja keras dan usaha yang dilakukan Lail dapat masuk di akademi perawat tersebut. Melalui karakter Lail tersebut, siswa dapat mengambil nilai positif dari sifat kemandirian dan pantang menyerah. 


\section{Sifat Sabar}

Karakter sabar dalam novel Hujan karya Tere Liye digambarkan melalui tokoh Lail. Dalam kisah cintanya, Lail memiliki sifat yang sangat sabar. Berawal dari bencana gempa bumi yang terjadi, ia diselamatkan oleh seorang anak laki-laki bernama Soke Bahtera. Kebersamaan sebagai kakak-adik antara kedua tokoh tersebut berubah menjadi rasa cinta. Namun karena terkendala waktu dan budaya, Lail tidak pernah menyampaikan perasaannya. Bertahun-tahun Lail tetap sabar menunggu Soke Bahtera mengungkapkan perasaannya. Melalui karakter Lail tersebut, siswa dapat mengambil nilai positif bahwa untuk mencapai segala sesuatu butuh proses, usaha, dan rasa sabar.

\section{Sifat Peduli}

Dalam novel Hujan karya

Tere Liye karakter Peduli digambarkan melalui tokoh Soke Bahtera. Seorang ilmuwan muda yang berprestasi dengan banyak membuat teknologi canggih. Sebagai tokoh yang berprestasi dan terkenal Soke Bahtera tetap memiliki rasa kepedulian yang tinggi terhadap orang lain. Hal ini ia tunjukkan dengan menyumbangkan pemikiran dan tenaga dalam pembuatan kapal untuk menyelamatkan umat manusia. Sikap kepedulian inilah yang bisa diambil oleh siswa dalam kehidupan sehari-hari.

\section{SIMPULAN}

Berdasarkan hasil penelitian dan pembahasan di atas, dapat disimpulkan beberapa hal sebagai berikut. Pertama, dalam novel Hujan karya Tere Liye ditemukan beberapa formasi ideologi. Formasi ideologi yang paling dominan adalah otoritarisme, sosialisme, vandalisme, kapitalisme, liberalisme, serta feodalisme. Formasi ideologi otoritarisme , feodalisme, dan vandalisme dilakukan oleh tokoh para pemimpin negara-negara subtropis dan tokoh Wali Kota, serta Soke Bahtera. Sementara formasi ideologi sosialisme dan liberalisme sebagai bentuk perlawanan ideologi dominan dilakukan oleh tokoh anggota konsorsium yang tergabung dari empat kepala negara, delapan gubernur, dan beberapa walikota kota-kota besar. Formasi ideologi kapitalisme ditanamkan melalui tokoh para ilmuwan dan beberapa kepala negara, dan walikota yang tergabung dalam konsorsium. Mereka sepakat untuk membiayai secara swasta untuk pembuatan kapal sebagai upaya untuk melawan dampak keputusan sepihak dari para pemimpin dunia.

Kedua, hegemoni kekuasaan di dalam novel Hujan karya Tere Liye berada di wilayah masyarakat sipil dan masyarakat politik. Para ilmuwan, empat kepala negara, dan delapan gubernur yang tergabung dalam anggota konsorsium merupakan tokoh luar yang melakukan hegemoni terhadap masyarakat dunia. Hegemoni yang terjadi dalam masyarakat politik dilakukan dengan cara paksaan untuk mencapai sebuah perubahan.

Ketiga, novel Hujan karya Tere Liye memiliki relevansi dengan pembelajaran Bahasa Indonesia di SMA. Melalui novel ini, siswa dapat mengambil nilai positif dalam kaitannya dengan pembentukan karakter dan kepribadian siswa. Siswa dapat memahami nilai sosial, moral, dan budaya melalui tokohtokoh yang digambarkan dalam novel. Melalui novel Hujan karya Tere Liye siswa dapat digunakan siswa untuk menambah pengalaman, 
pengetahuan, dan wawasan yang dapat digunakan sebagai media untuk membentuk kepribadian diri.

\section{DAFTAR PUSTAKA}

Chatman, Seynour. 1980. Story and iscourse: Narrative Structure in Fiction and Film. Ithaca: Cornell University Press.

Damono, Sapardi Djoko. 1984. Sosiologi Sastra Sebuah Pengantar Ringkas. Jakarta Pusat: Pusat Pembinaan dan Pengembangan Bahasa.

Faruk. 2003. Pengantar Sosiologi Sastra. Yogyakarta: Pustaka Pelajar.

Harjito. 2014. Hegemoni Gramsci dalam Sastra Indonesia: Student Hijo, Nasionalisme, dan Wacana Kolonial. Semarang: UPGRIS Press.

Homba. 2016.

Jabrohim. 2015. Teori Penelitian Sastra. Yogyakarta: Pustaka Pelajar.

Kamus Besar Bahasa Indonesia (Online)

Kurniawati., Diyan. 2016. "Proses Hegemoni Sosial Dalam Novel Tanah Tabu Karya Anindita S. Thyaf. SALINGKA. Nomor 1. Volume 13.

Manan, Muasiful. 2015. "Hegemoni LakiLaki Pribumi Dalam Fenomena Asmara Tradisi Etnis Tionghoa Pada Novel Sutra Bakti Karya Sesco Saragih".

CITRA\%20PEREMPUAN\%20DALA M\%20NOVEL/Lib\%20Unnes.pdf

Moloeng. 2006. Metodologi Penelitian Kualitiatif. Bandung: PT Remaja

Rosdakarya.

Nugroho. 2000. "Tinjauan Kritis Liberalisme dan Sosialisme". Jurnal Ilmiah Bestari. Nomor 30. Tahun XIII.

Patria, Nezar dan Arief, Andi. 2009. Antonio Gramsci Negara \& Hegemoni. Yogyakarta : Pustaka Pelajar.

Simon, Roger. 2004. Gagasan-Gagasan Politik Gramsci. Yogyakarta: Pustaka Pelajar.

Sugiyono. 2012. Metode Peneltian Kuantitatif Kualitatif dan $R \& D$. Bandung: Alfabeta.
Tere Liye. 2016. Hujan. Jakarta: PT Gramedia Pustaka Utama. 